\title{
Creation and Validation of an Educational Booklet on the Hypertensive Pregnancy Syndrome
}

\begin{abstract}
Lia Maristela da Silva Jacob1, Daniela Gardano Bucharles Mont'Alverne ${ }^{2}$, Joselany Áfio Caetano ${ }^{3}$, Maria Albertina Rocha Diógenes", Antonieta Keiko Kakuda Shimo Ana Maria Martins Pereira ${ }^{6}$, Reginaldo Roque Mafetoni ${ }^{7}$, Cláudia Jeane Lopes Pimenta ${ }^{8}$
\end{abstract}

\section{Abstract}

Objective: To develop and validate an educational booklet about gestational hypertension syndrome.

Method: Methodological research divided into five stages: focus groups with pregnant women about gestational hypertension syndrome; literature review; construction and validation of a booklet on gestational hypertensive syndrome; preparation of texts; consulting with a graphic designer to create the figures/illustrations. The validation of the booklet has been done by the analysis of nine expert judges on the subject and 30 pregnant women, selected by convenience.

Results: Regarding the content validity index, it was higher in all the aspects, higher than 0.9. It was verified high level of agreement between the judges and pregnant women, in the appearance aspect of the booklet on five topics.

Conclusion: The material is effective both in the technical aspects, as in the communication favor with the audience, reaching the understanding of participants in the prevention of hypertension syndrome.
1 Specialist in Obstetrical Nursing, School of Public Health of Ceará. Master of Public Health, University of Fortaleza. Doctoral Student in Health Sciences from the Nursing School at the State University of Campinas, *

2 Specialist in Cardiorespiratory Physiotherapy, Heart Institute of Medicine School of the University of São Paulo. Doctor of Sciences in the area of Pneumology Concentration, University of São Paulo. Professor in Physiotherapy Course of the Federal University of Ceará. Coordinator of the University Hospital Rehabilitation Unit Walter Cantídio (UFC-EBSERH Branch), *

3 Master and Ph.D. in Nursing, Federal University of Ceará. Associated Professor I in Nursing Program, Federal University of Ceará, *

4 Master of Community Health and Ph.D. in Nursing from the Federal University of Ceará. Adjunct Teacher I in Nursing Course, University of Fortaleza, *.

5 Master in Fundamental Nursing and Doctor in Nursing from the University of São Paulo. Teacher from the Nursing School at the State University of Campinas, *

6 Master in Public Health. Professor at the Nursing Undergraduate Program, Faculty Earth Northeast. Assistance nurse at the Center of Normal Birth, *

7 Master and Doctoral Student in Health Sciences from the Nursing School at the State University of Campinas. Professor of Graduate Nursing at the University of São Paulo, *

8 Bachelor of Nursing, Federal University of Campina Grande, *.

Contact information:

\section{Keywords}

Lia Maristela da Silva Jacob.

Gestational Hypertension; Validation Studies; Teaching Materials. 


\section{Introduction}

Hypertension is a clinical problem, and when associated with pregnancy, it is one of the causal factors of mortality and maternal-fetal morbidity, being at the origin of several complications, with prematurity, fetal growth restriction, fetal or perinatal death, placental abruption, uterine rupture, hemorrhage, among others [1].

The epidemiological framework for maternal health is critical as well as the fragility of assistance to this population seen in developing nations. For every woman who dies, another 20, that is $10 \mathrm{mi}-$ llion women each year are affected by illnesses related to pregnancy, childbirth and postpartum, with serious consequences for them, their children, their families, and society. In Brazil, in 2005, there were 1,619 maternal deaths (maternal mortality ratio of 73.9/100,000 live births), mostly preventable if they had been timely and appropriate interventions were used [2].

Gestational hypertension continues to be responsible for this situation, due to being ignored or not valued correctly and for persisting a significant controversy about the best method of prevention and treatment of different hypertensive disorders. Therefore, it is disappointing to note that this scenario remains unchanged over the years, and in it, gestational hypertension is still a serious and fatal complication in developed countries, with more serious situations even in poor or developing nations [3].

The difficulty of access to family planning, high incidence of multiparity and poor awareness of reproductive risk are often the main factors responsible for this reality, common to many poor or developing countries, where chronic multiparous hypertensive are subjected to the progressively greater risk of each new pregnancy [4].

However, by this fact, the health team conducting the prenatal should also prioritize health education activities, among other behaviors attached to that assistance. In this scenario, it is worth highlighting the contributions of education to human develop- ment, to the adoption of positive behaviors and the use of appropriate coping strategies.

Health education is understood as a process oriented and planned to use strategies that encourage the autonomy of individuals, assuming shared and not policy actions, enabling the making easy decisions and the selection of alternatives in an appropriate context of information, cognitive abilities, and support [5].

It is worth mentioning the importance of nurses in this communication process established in the educational activity as they play a critical role in the health-disease of women, traversing all health care levels. Nurses are responsible for conducting educational activities for women and their families, to conduct prenatal low-risk consultations, request routine examinations and guide treatment as the service protocol, guiding identified risk pregnant women for medical care, carry out activities with the group and waiting room, and provide prenatal booklet duly updated [6].

In this context, it is important the inclusion of educational materials to health promotion instruments, facilitators of the educational process in health, able to make the co-participant patients in their care, which provides the dialogical integration of nurse-client and family, enabling the construction multidimensional knowledge readily available, inexpensive, able to empower patients and families [7].

Before the gestational hypertension syndrome (GHS) problems to public health and indicators of maternal and neonatal mortality, the research aims to develop and validate an educational booklet about gestational hypertension syndrome.

\section{Method}

This is a methodological research, by focusing on the development, evaluation and improvement of an instrument [8]. This type of study aims to develop, validate and evaluate tools and research techniques, having as its goal the development of a 
reliable instrument and can be subsequently used by other researchers.

To ensure the quality of the elaboration of the material, assumptions have been used to explain about the stages of the construction process of educational material for health care [9]. The research was conducted in the city of Fortaleza, Ceará, in the period from February to November 2014.

In the first stage, it was initially performed a focus group with pregnant women about the knowledge of gestational hypertensive syndrome. This time was for researchers to understand better the doubts and anxieties of pregnant women regarding this issue, although it was not proposed in the model [9].

Then, a literature review was conducted on the subject by organizing a systematic and chronologically the essential information to be addressed in the educational material. The booklet was entitled "Prevention of Gestational Hypertension Syndrome-GHS", addressing prevention of GHS, complications, and treatment of its contents.

From the results of the literature review and focus groups, the texts were elaborated, clearly and succinctly written to achieve a language accessible to the entire population, as well as coherently organized.

Following, a consultation with a graphic designer was held to create the figures/illustrations to ensure easy to understand and the attractiveness. The programs used in this step were Corel Draw Essentials ${ }^{\circledR}$ and Adobe Photoshop ${ }^{\circledR}$.

This booklet preparation stage was following recommendations that describe the aspects of the language, with illustration and layout that health professionals should consider preparing printed educational materials to make them readable, understandable, efficient and culturally relevant [10]. In the end, the booklet totaled eight pages, divided into the following topics: Definition of the syndrome; Classification; Signals and symptoms; Risk factors; Consequences; HELLP syndrome; Prevention/ treatment; and Tips for a healthy pregnancy.
The validation of the booklet was made through the analysis of expert judges on the subject and the audience. Analysis of judges aimed to evaluate the content and appearance of the booklet. Nine judges acting in the obstetric area, public health and who have experience in the health promotion area and the construction or evaluation of educational and teaching materials, all with at least two years of training were selected. Some studies report that at least three judges are needed for this step, and that number must be unique for the condition of a tie [11].

Professionals who reached the inclusion criteria were invited to participate in the study through Letter of Invitation, via e-mail or in person. A detailed explanation of the research proposal, its procedures and reiterated the importance of collaboration of each expert was made.

It was delivered together with the booklet, a questionnaire for them, in which the experts were asked to record their suggestions to improve the material. This questionnaire was adapted from the questionnaire used [5] that was used to validate a material for the prevention of vertical transmission of HIV. This instrument allowed the experts make recommendations regarding the structure, content, language and illustrations contained in the booklet.

The second validation phase of the material was with the help of the women. This step was essential so that they could indicate the difficulties encountered when it came to understanding the language and illustrations contained in the booklet.

It is ideal not only delivered the printed material but that communication between the nurse, the patient and family is efficient, with exchanges of experience between them, in which participants are active in the construction of their knowledge. Therefore, this initiative must be placed in a larger context of health education, providing a continuum of health care [12].

In this phase 30 pregnant women at any gestational age were included in the study, who were in 
prenatal care in some unit of primary health care in the city of Fortaleza/CE randomly chosen who could read and write, and who were not carriers of the gestational hypertension syndrome.

It was asked the participants to read the booklet and its validation in the aspects related to language and illustrations contained in this material, as well as an overall assessment of the relevance of the booklet in these aspects, using an adapted questionnaire [5].

The instrument of the judges has 52 items distributed in seven evaluative aspects, two of content and the remaining five of appearance. The answers to the questions were submitted in the form of Likert scale. The levels ranged from $1=$ strongly disagree, 2 = partially agree, $3=$ agree and $4=$ strongly agree. The instrument directed to the target audience totaled in 41 items distributed in five evaluative aspects of appearance. The answers to the questions were presented as "yes", "no" and "in part".

After collecting data, there was an analysis of data from each evaluator, both of expert judges, like pregnant women. Socio-demographic analysis and gynecological-obstetric pregnant women and socio-demographic of expert judges were held.

As for the booklet content validity, the Content Validity Index (CVI) was applied, which is used by several other authors [13], which uses Likert scale with scores ranging from one to four and is based on responses of judges to the degree of relevance of each item [8].

To evaluate the booklet as a whole, a recommended calculation form was used [8], wherein the sum of all CVI calculated separately is divided by the number of instrument items. As nine experts validated the booklet, literature recommends CVI cutoff of 0.78 [13].

The validity of appearance was held both by the judges as the target audience, considered validated items that obtained a minimum level of agreement of $75 \%$ in positive responses [13]. For the judges, it was considered positive response options 3 and 4 (agree and strongly agree, respectively) and for pregnant women the option "yes."

This study was approved by the Research Ethics Committee of the University of Fortaleza, with opinion 652,103, and all participants signed an informed consent form [14].

\section{Results}

The study included nine judges, seven (77.8\%) females and two (22.2\%) male, mean age of $40 \pm 16$ years old. Out of them, seven (77.8\%) were nurses, and two (22.2\%) were physicians, with an average training time consisted of $12 \pm 16$ years, and working time in the average area of $11.8 \pm 15.6$ years. Of these, four (44.4\%) were masters and five (55.6\%) were specialists.

In the group of 30 pregnant women, the average age was $27.2 \pm 6.8$ years old, with a mean gestational age of $21.1 \pm 8.7$ weeks and an average of the $4.3 \pm 1.5$ number of consultations in the prenatal period. The average number of pregnancies was $2 \pm 1.1$ and $0.1 \pm 0.3$ for abortions. Concerning the marital status, 10 were single (33.3\%), seven (23.3\%) were married, and 13 (43.3\%) had a stable union. On education, the average time was $9 \pm \pm$ 1.8 years. About religion, 15 (50\%) were Catholic, 12 (40\%) were Protestant, and three (10\%) reported other faiths.

As for the CVI of the judges, there was a high level in all aspects, exceeding 0.9 (Figure 1).

A high level of agreement among the judges in the appearance aspect of the booklet on the five topics and the aspect of lower index literary presentation with 93\% concordance was observed (Figure 2).

The same was observed among pregnant women, with a high level of agreement, with the topic with the lowest rate of Readability and Features of 96\% (Figure 3). 
Figure 1: Booklet Content Validity Index of Judges about the scientific accuracy.

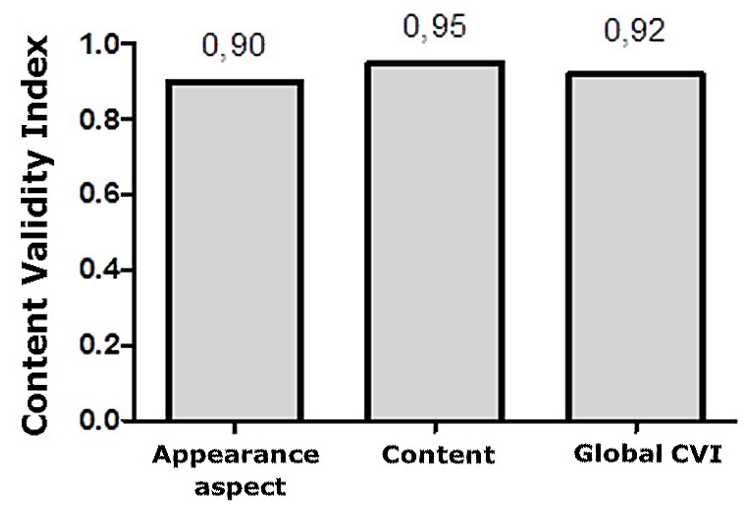

Figure 2: Agreement level among judges in the appearance aspect.

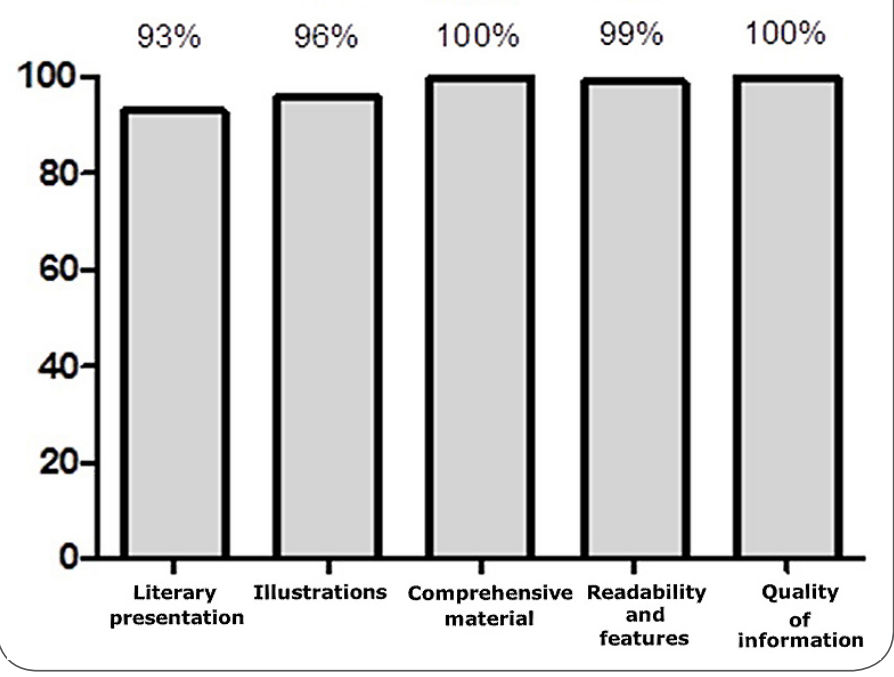

Figure 3: Agreement level among pregnant women in the appearance aspect.

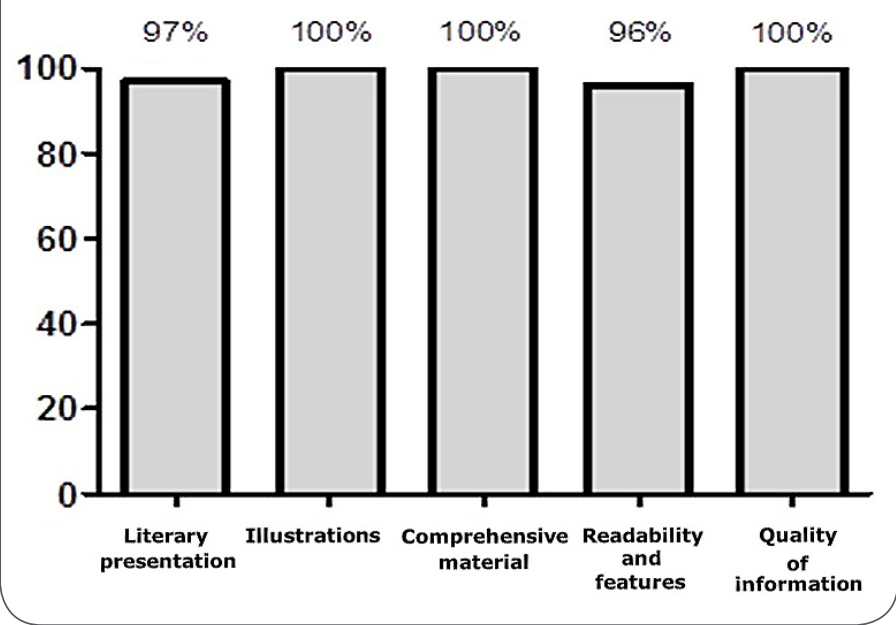

\section{Discussion}

Health promotion and disease prevention are undoubtedly the best way to quality care. Based on this context, it was emphasized that the construction of educational materials is a favorable method of the development of actions in the health field.

The use of printed educational materials in health care is common practice in the Unified Health System (UHS) [9]. Brochures, booklets, and health care guides can promote significant results for the participants of the educational activities. Also, the language used was appropriate to the local culture, to facilitate the pregnant women understanding. In this sense, the words were preferentially used in popular use, especially colloquial. The content of the booklet was composed of information addressed in the overall context of the GHS prevention, treatment, and complications.

It is believed that the use of simple language promotes the identification of the patient with the text and keep their initiative in the health education process, enabling a light, pleasant and easy reading to understand. It is crucial to prepare the text to engage as much as possible with the patient, adopting some strategies in the production of educational material to encourage this dialogicity [15].

During the process of construction of the booklet, it was realized the importance of the participation of pregnant women, because the contribution of this health promotion for materials depends on the principles and forms of communication involved in the elaboration process [16]. Only $23.3 \%$ of women said they had guidelines for the GHS by health professionals during consultations, which means that only seven participants had access to the syndrome prevention information.

Evaluation of pregnant women in the material was significant, given that the level of agreement between them, evaluating the appearance of agreement was high, highlighting the illustrations, the understanding of the material and the quality 
of information, both $100 \%$ agreement. The participatory approach used during the phase of identifying the educational needs of pregnant women was paramount. This approach allowed the active contribution of participants in the indication of the booklet of content to meet their demands.

The preference for building a jointly material between service users and health professionals favors an educational activity that seeks to exchange experiences and information, reflection and questioning on the issues, assuming their everyday life experiences as a source of knowledge and the transforming action of reality [16].

The validation process by the judges and by pregnant women was very relevant, as it was feasible to do an analysis of the technical and cultural, involving the collective knowledge. The nine judges who participated in the study were from the area of health, working in maternity care in public health and experience in health promotion. For the validation of content, it is necessary the judges be experts in the area of interest since only then they can properly evaluate the relevance of the content of the submitted items [16].

The CVI, as shown in Figure 1, was greater than 0.9 , showing statistically significant aspects: scientific accuracy and content covered in the material. It should be considered what is the objective to inform and expectations in an educational material, as this produced effectively, changing the reality of a population [17].

Referring to preventive measures during pregnancy, monitoring during prenatal care as directed by the Ministry of Health and the recognition and treatment of early signs of disease and attendance in consultations, it constitute unquestionable procedures to monitor the pregnancy to birth [18]. In this sense, the positive evaluation of pregnant women and judges as to elaborate educational booklet is of paramount importance to infer the efficacy and effectiveness of this technology for the prevention of GHS.
We emphasize that this syndrome is an increase in blood pressure in a pregnant woman, who before pregnancy she did not have a hypertensive framework (normotensive) and can affect any pregnant woman. Thus, there are some predisposing factors such as diabetes, hypertension, kidney and heart disease or, multiple pregnancies, cancer, first pregnancy, young pregnant women [6].

The material shows that among the complications arising from gestational hypertension, it is distinguished by its severity, the HELLP syndrome, which, although the cause is not yet fully elucidated, it can cause some serious complications such as heart, lung, kidney failure, among others [19].

There was a concern for addressing risk factors since their knowledge by pregnant women favors the prevention of the syndrome and its complications considerably. Those who have higher incidences are vascular disease (diabetes mellitus, hypertensive renal disease, idiopathic hypertension), psychological state (emotional conflicts determine greater release of catecholamines), multiple pregnancy, family history of pre-eclampsia and eclampsia, socioeconomic status (as lower, higher nutritional deficiencies and poorer care during prenatal), obesity, diverse paternity, primiparity (age below 17 years old and above 40 years old) and black race [20].

Still focusing on prevention, it was punctuated the importance of pregnant women participation in prenatal care, which is in this period that the woman should be better targeted to live childbirth positively, have less risk of complications postpartum and more success breastfeeding [16].

Completing this thought, there were some tips exposed for a healthy pregnancy, how to follow the guided behaviors by health professionals, have a healthy diet (foods with low sodium, preference for chicken, fish, fruits and vegetables), avoid soft drinks, sweets, excess of pasta, animal fats, fried foods, canned food (ham, alcoholic beverages and tobacco), take 2.5 to 3 liters of fluid a day, eat 
slowly, at regular times and walk regularly (at least three times a week) [20].

This study presents as limitations the use of regionally in the Northeast, the State of Ceará, which may limit the use of the booklet in other regions of the country.

\section{Conclusion}

The main purpose of creation of this educational technology has been promoting and expanding the knowledge of pregnant women concerning hypertensive syndrome, focusing on health promotion. The high level of agreement on the evaluation of judges and pregnant women showed that the material is effective both in the technical aspects, as in the communication favor with the audience, reaching the understanding of participants about the prevention of GHS.

Based on this study, it is sure that the participation of pregnant women in the process of construction and validation of the material was extremely relevant, assisting in defining the vocabulary, illustrations and structuring of the booklet, and contributing to the positive understanding of it.

The study reinforces the importance of using educational materials, contributing not only to the teaching and research, but also as an important strategy for health promotion, and a strong ally of the professionals working in primary care settings for health, contributing increasingly more for quality care.

\section{References}

1. National High Blood Pressure Education Program: Report of the National High Blood Pressure Education Program Working Group on High Blood Pressure in Pregnancy. Am J Obstet Gynecol [Internet], 2000; 183(1): S1-S22. Available from: http://www.ncbi.nlm.nih.gov/pubmed/10920346

2. Brasil. Ministério da Saúde (BR). Mortalidade materna no Brasil: principais causas de morte e tendências temporais no período de 1999 a 2010. In: Saúde Brasil 2011: uma análise de situação de saúde e a vigilância da saúde da mulher [Internet]. Brasília: Ministério da Saúde; 2012. p. 347-56. Available from: http://repositorio.unb.br/bitstream/10482/12834/1/CAPITULO CesarianasNoBrasil.pdf

3. Souza AR, Amorim MR, Costa AA, Neto CN. Tratamento antihipertensivo na gravidez. Acta Med Port [Internet], 2010;23(1):7784. Available from: http://www.actamedicaportuguesa.com/

4. Narchi NZ, Cruz EF, Gonçalves R. O papel das obstetrizes e enfermeiras obstetras na promoção da maternidade segura no Brasil. Ciênc Saúde Coletiva [Internet], Rio de Janeiro, 2013 Apr; 18(4):1059-1068. DOI: http://dx.doi.org/10.1590/ $\underline{\mathrm{S} 1413-81232013000400019}$

5. Lima ACMACC. Construção e Validação de Cartilha Educativa para prevenção da transmissão vertical do HIV. Dissertação [Mestrado em Enfermagem] - Universidade Federal do Ceará; 2014.

6. Brasil. Ministério da Saúde (BR). Gestação de alto risco: manual técnico [Internet]. Série A. Normas e Manuais Técnicos. Brasília: Departamento de Ações Programáticas Estratégicas; 5. ed. 2012. Available from: http://bvsms.saude.gov.br/bvs/publicacoes/ manual tecnico gestacao alto risco.pdf

7. Barros EJL, Santos SSC, Gomes GC, Erdmann AL. Gerontotecnologia educativa voltada ao idoso estomizado à luz da complexidade. Rev Gaúcha Enferm [Internet], Porto Alegre, 2012 June; 33(2):95-101. DOI: http://dx.doi.org/10.1590/S198314472012000200014

8. Polit DF, Beck CT. Fundamentos de pesquisa em enfermagem: avaliação de evidência para a prática da enfermagem. $7^{\text {th }}$ ed. Porto Alegre: Artmed; 2011.

9. Echer IC. Elaboração de manuaias de orientação para o cuidado em saúde. Revista Latino-Americana de Enfermagem [Internet], Ribeirão Preto, 2005 Sep/Oct; 13(5):754-7. DOI: http://dx.doi. org/10.1590/S0104-11692005000500022

10. Hoffmann T, Warrall L. Designing effective written health education materials: considerations for health professionals. Disabil Rehabil [Internet], 2004 Oct; 26(9):1166-73. Available from: http://www.ncbi.nlm.nih.gov/pubmed/15371031

11. Lynn MR. Determination and Quantification Of Content Validity. Nursing Research [Internet], 1986 Nov-Dec; 35(6):382-386. Available from: http://www.ncbi.n/m.nih.gov/pubmed/3640358 
12. Fonseca LMM, Leite AM, Mello DF, Silva MAI, Lima RAG, Scochi CGS. Tecnologia educacional em saúde: contribuições para a enfermagem pediátrica e neonatal. Esc Anna Nery [Internet], Rio de Janeiro, 2011 Jan/Mar; 15(1):190-196. DOI: http://dx.doi. org/10.1590/S1414-81452011000100027

13. Joventino ES, Oriá MOB, Sawada NO, Ximenes LB. Apparent and content validation of maternal self-efficiency scale for prevention of childhood diarrhea. Rev Latino-Am Enfermagem [Internet]. 2013; 21(1):371-9. DOI: http://dx.doi.org/10.1590/ S0104-11692013000100012

14. Brasil. Ministério da Saúde (BR). Resolução No 466, de 12 de Dezembro de 2012 [Internet]. Conselho Nacional de Saúde; 2012. Available from: http://conselho.saude.gov.br/resolucoes/2012/ Reso466.pdf.

15. Camacho ACLF, Abreu LTA, Leite BS, Mata ACO, Tenório DM, Pires RS. Validation of information booklet about the elderly with dementia: an observational-transversal study. Online Brazilian Journal of Nursing [Internet]. 2013; 12(1):145-61. DOI: http://dx.doi.org/10.5935/1676-4285.20134010

16. Rebert LM, Hoga LAK, Gomes ALZ. Process of construction of an educational booklet for health promotion of pregnant women. Revista Latino-Americana de Enfermagem [Internet], 2012; 20(1):101-108. DOI: http://dx.doi.org/10.1590/S010411692012000100014

17. Zombini EV, Pelicioni MCF. Estratégias para a avaliação de um material educativo em saúde ocular. Rev Bras Crescimento Desenvolvimento Hum [Internet], São Paulo, 2011; 21(1):51-8. Available from: http://pepsic.bvsalud.org/scielo.php?pid=S0104$12822011000100006 \&$ script=sci arttext

18. Figueiredo NMA, Viana DL, Machado WCA. Tratado Prático de Enfermagem. $2^{\text {nd }}$ ed. Fernandes MM, editor. São Paulo: Yendis Editora Ltda; 2008.

19. Carvalho ARMR, Amorim MMR, Katz L, Souza ASR, Santos ARVD, Lima ALMV. Ressonância magnética hepática em puérperas estáveis com síndrome HELLP. Rev Assoc Med Bras [Internet], São Paulo, 2008 Sept/Oct; 54(5):436-41. DOI: http://dx.doi.org/10.1590/S0104-42302008000500018

20. Santos ZMSA, Oliveira FML, Silva MP, Nascimento JC, Feitoza JS, Nascimento JSFRO. Fatores de risco para a síndrome hipertensiva específica da gravidez. RBPS [Internet], 2009; 22(1):48-54. DOI: 10.5020/18061230.2009.p48
Publish in International Archives of Medicine

International Archives of Medicine is an open access journal publishing articles encompassing all aspects of medical science and clinical practice. IAM is considered a megajournal with independent sections on all areas of medicine. IAM is a really international journal with authors and board members from all around the world. The journal is widely indexed and classified Q1 in category Medicine. 